IZA DP No. 8748

The Impact of Multilingualism on Spanish Language Acquisition among Immigrants in Spain

Santiago Budría

Pablo Swedberg

December 2014 


\title{
The Impact of Multilingualism on Spanish Language Acquisition among Immigrants in Spain
}

\author{
Santiago Budría \\ CEEAPIA and IZA
}

\section{Pablo Swedberg}

St. Louis University

\section{Discussion Paper No. 8748 \\ December 2014}

\author{
IZA \\ P.O. Box 7240 \\ 53072 Bonn \\ Germany \\ Phone: +49-228-3894-0 \\ Fax: +49-228-3894-180 \\ E-mail: iza@iza.org
}

Any opinions expressed here are those of the author(s) and not those of IZA. Research published in this series may include views on policy, but the institute itself takes no institutional policy positions. The IZA research network is committed to the IZA Guiding Principles of Research Integrity.

The Institute for the Study of Labor (IZA) in Bonn is a local and virtual international research center and a place of communication between science, politics and business. IZA is an independent nonprofit organization supported by Deutsche Post Foundation. The center is associated with the University of Bonn and offers a stimulating research environment through its international network, workshops and conferences, data service, project support, research visits and doctoral program. IZA engages in (i) original and internationally competitive research in all fields of labor economics, (ii) development of policy concepts, and (iii) dissemination of research results and concepts to the interested public.

IZA Discussion Papers often represent preliminary work and are circulated to encourage discussion. Citation of such a paper should account for its provisional character. A revised version may be available directly from the author. 
IZA Discussion Paper No. 8748

December 2014

\section{ABSTRACT}

\section{The Impact of Multilingualism on Spanish Language Acquisition among Immigrants in Spain}

This article uses micro-data from the Spanish National Immigrant Survey to analyze the acquisition of Spanish language skills for immigrants in Spain. The motivation of the paper is threefold. Language skills are important for an individual's labour market performance, Spain offers an important non-English speaking country instance and the main novelty of our paper is to explore the impact of speaking multiple foreign languages on host language learning for immigrants. The results reveal a strong positive association between multilingualism and the probability of reporting good or very good Spanish language proficiency for immigrants in Spain.

JEL Classification: J15, J24, J61

Keywords: immigration, language proficiency, education

Corresponding author:

Pablo Swedberg

Department of Business and Economics

Saint Louis University

Av. del Valle 34

28003 Madrid

Spain

E-mail: swedberg@slu.edu 


\section{Introduction and background}

It was not until the 1980s that economists began to study and consider immigrant language skills as a form of human capital and analyzed it in its economic perspective (Carliner, 1981; McManus, Gould, \& Welch, 1983; Tainer, 1988). Following Gary

Becker's theory of human capital, greater fluency in the destination language is expected to enhance earnings among immigrants. Host language proficiency enhances productivity on the job by making the worker more efficient in performing particular tasks and/or by reducing the cost of communication within the firm. Moreover, proficient workers are in a better position to obtain information about job opportunities and earnings, and to transmit information about their skills to employers. Immigrants with greater fluency in the dominant language are also more efficient consumers for a number of reasons. They can, for example, communicate with a wider range of merchants, read advertising, labels and directions more efficiently. As a consequence they can pay a lower real price than immigrants lacking language proficiency and thereby attain a higher level of utility from their constrained expenditures. There is in fact a significant literature examining how English language proficiency affects earnings positively in the US, Canada, the UK and Australia (Carliner, 1981, McManus et al., 1983, Grenier, 1984, Tainer, 1988, Rivera-Batiz, 1992, Chiswick, 1991, Dustmann \& Fabbri, 2003, Lui, 2007, Chiswick \& Miller, 1999, 2010). Likewise, Dustmann \& van Soest $(2001,2002)$ for Germany, several studies in Israel (Chiswick, 1998, Chiswick \& Repetto, 2001, Berman et al. 2003) and Budría and Swedberg (2014) for Spain show the positive effect of host language proficiency on immigrant earnings.

In spite of the significant number of studies analyzing the determinants of host language 
proficiency of immigrants, most studies using census data on destination language proficiency have been carried out in three predominantly English-speaking countries Australia, Canada and the United States (Chiswick and Miller 1994, 1995, 1998, 2001, 2008, Epenshade and Fu, 1997, Shields and Price 2002, Chiswick, Lee and Miller, 2004, 2005, Tubergen and Kalmijn, 2009, Kulkarni and Hu, 2014, Rebhun, 2014). In non-English speaking countries, research has also been performed for Hebrew language acquisition in Israel (Chiswick, 1998, Chiswick and Repetto, 2001, Raijman 2013) and for German fluency among immigrants in Germany (Dustmann, 1994, Isophording and Otten, 2013).

The purpose of this paper is to explore the determinants of Spanish language acquisition among immigrants in Spain. The motivation of the paper is threefold. First, the process of acquiring an additional language can be affected by the fact that learners have learned a foreign language previously. The impact of multilingualism may show up in the development of more sophisticated learning methods, a wider array of communicative strategies and stronger metalinguistic and cultural awareness (Bialystock, 1988). Being multilingual enhances cognitive and sensory processing which in turn leads to a clearer signal for learning. Research in Spain (Sanz, 2000) and in other countries (Cenoz 2013) from a pshycolinguistic perspective shows that being bilingual strengthens subsequent foreign language acquisition for native speakers. A recent report by the European Comission (2009) on multilingualism concludes that thinking, learning, problem solving and communicating show signs of enhancement through multilingualism. Additionally, there are changes in the neurological processing and brain structure of multilingual individuals. These people posses a bilingual advantage that affects their subcortical brain areas traditionally associated with sensory 
processing (Marian and Shook, 2012). This paper explicitly test whether, conditional on a vast array of socio-economic characteristics, multilingual immigrants are more prone to become proficient in Spanish.

Secondly, given that language skills affect an individual's labour market performance, the immigrants' income and poverty levels will be greatly influenced by their language proficiency. This will ultimately affect their social and cultural integration to the host country society. It has been shown that immigrants experience a negative wage gap with respect to natives and this initial gap decreases gradually as immigrants learn the host language. The degree of earnings assimilation is found to differ across studies $(\mathrm{Hu}$, 2000, Friedberg, 2002, Lubotsky, 2007, Adsera \& Chiswick, 2007, Beenstock et al. 2010). Amuedo-Dorantes \& de la Rica (2007) find that there is a $15 \%$ wage gap reduction in their initial 5 years of residence for immigrants in Spain. Likewise Lacuesta et al. (2009) find that the initial wage differential with respect to natives with the same observable characteristics decreases with time spent in Spain. According to their estimates, assimilation of legal immigrants occurs rapidly, with a 50\% reduction of the initial wage gap in the first 5-6 years since their arrival. All in all, the nativeimmigrant wage gap partly reflects the fact that migrants cannot fully use their human capital attributes. While the focus of the present paper is not on the impact of language fluency on earnings and the degree of assimilation experienced by immigrants, it addresses the learning process of one of the most important human capital components in the country of residence: language ability. Immigrants who possess strong language proficiency are also less likely to be overqualified at their job (Blázquez \& Rendón, 2012), most likely because they are more efficient in seeking and obtaining employment where their skills are most highly rewarded. Because it fulfills a number of functions, 
language plays a crucial role in the immigrant's integration process.

Thirdly, Spain offers an important case study since most studies of host language proficiency acquisition have been carried out for English-speaking destinations. As English has become an international lingua franca it would be important to know whether similar patterns are found in non-English speaking countries. The findings for Israel and Germany parallel those of the other Anglo-Saxon countries but additional evidence from a Spanish-speaking country would proof very important as a test of the robustness of the model across destination languages. Spanish is the fourth most widely spoken language in the world by number of speakers and the second most widely spoken language by number of native speakers. Moreover, the great majority of the research has been carried out in countries with a long tradition and history of immigration, whereas in Spain the great bulk of immigrants arrived after 1998. This makes the immigrants in Spain more homogenous in terms of time spent in the host country and degree of social and economic assimilation. Furthermore, the case of Spain is particularly interesting, due to the massive migration flows experienced over the past decade. According to the OECD (2013) the stock of foreign-born population increased from $4.9 \%$ of the total population in 2000 to $14.6 \%$ in 2011, which represents 6.738 .000 immigrants. As a result Spain ranks fifth among OECD countries in stocks of foreignborn population. However, the economic downturn initiated in the third quarter of 2008 has slowed down migration inflows significantly and increased migration outflows substantially. As a result of the decline in new entries (OECD, 2013) and the increase in return migration and emigration due to worsening labour market conditions, Spain experienced negative net migration in 2011 for the first time since 1990. In particular Colombians, Ecuadorians, Bolivians and Peruvians accounted for almost half of the 
leavers in 2013 (INE, 2014). Indeed language may play a crucial role in return migration since five of the 10 largest immigrant populations in Spain come from Spanish-speaking countries. Since there are no other Spanish-speaking countries in the EU and Spaniards show very poor foreign language skills (Eurobarometer 2012), many young Spaniards tend to stay in Spain competing for jobs with Spanish-speaking immigrants.

The paper is organized as follows. Section 2 reviews the theoretical considerations. Section 3 describes the dataset, the estimating sample and the Spanish language proficiency question.

\section{Theoretical considerations}

Immigrant destination language can be analyzed within the human capital framework. In this context, the acquisition of host language skills has benefits that affect consumption and labor market outcomes as mentioned earlier, but there is also a financial cost of acquiring these skills as well as an opportunity cost derived from the foregone earnings while learning the host language. In fact these investments are made in anticipation of future benefits that may be in the form of higher earnings in the labor market, lower costs of consumption, greater political involvement or larger social networks, to name just a few.

Following Chiswick and Miller -1992, 1998, and 2008, we categorize the various factors that affect the acquisition of foreign language skills as exposure, efficiency, and economic incentives. We now summarize their main hypothesis. Exposure can happen

either before or after immigration. Pre-immigration exposure depends on the degree to 
which the destination language is used in the origin country and the study of the language in the home country. Post-immigration exposure will mainly depend on the duration of residence, assuming that the immigrant has lived in the country continuously. A quadratic form will also be added to the model to capture the effect of an additional year in the destination country since the effect of duration is likely to be non-linear and decreasing. In other words, proficiency increases rapidly in the first years, but at a decreasing rate. An immigrant has a stronger incentive to invest in foreign languages shortly after arrival to benefit from better language proficiency in the labor market and in consumption activities as soon as possible.

Furthermore, the different languages spoken by the household members may also impact the individual's host language proficiency. Chiswick, Lee, and Miller (2005) show strong correlations between the different family members' dominant language fluency skills. In particular, they show that correlations in destination language proficiency are stronger between spouses than between parents and children. Thomas (2010) shows that English proficiency among African immigrants in the U.S. is more strongly associated with their mother's than with their father's host language proficiency and that their English language ability increases with the number of English-proficient siblings in the household. Likewise, Medvedeva (2012) suggests that adolescent language choices in parent-child interactions in the U.S. tend to reflect their parents' ability to speak the destination language rather than their own preferences. Finally Goza and Kawamura (2013) argue that among Japanese-American young immigrants those whose mothers were born in Asia are more likely to speak Japanese than those with only an Asian-born father. Moreover, when marriage takes place after migration, it is more likely that the spouse is not proficient in the immigrant's mother 
language and this may facilitate the use and learning of the destination language.

Children have greater exposure to the destination language and culture than do their parents. Being at school and arriving at a younger age allows them to learn a new language quicker than their parents. As a consequence the impact of children on their parents’ destination language acquisition is significant, but complex. On the one hand, more rapid learning of the destination language amongst children may enable them to teach their parents the dominant language skills. On the other hand, children may serve as translators, reducing the incentive for their parents to learn the destination language. Since the latter impact is more likely to happen in consumption activities rather than work activities, mothers are more likely to be negatively affected. Children may also affect labor supply, especially among females, reducing the chance and incentive to acquire foreign language skills. Finally, parents who seek to transmit the culture of their home country to their children may encourage the learning of the home language to enable them to communicate with their grandparents and cousins or facilitate return migration in the future, limiting the chance to develop destination language skills amongst family members. Children thus have positive (teaching) and negative (the rest) effects on their parents' host language acquisition. As a consequence, the net impact is ambiguous and may differ between genders. The impact is more likely to be negative for the mother. Chiswick, Lee and Miller (2005) find that having children has a negative impact on the mother's destination language proficiency, but not on the father's.

Interestingly, our data includes information on whether the immigrant has children and if their children are fluent in Spanish. We include both variables for the immigrants' children; this allows us to separate the positive teaching effect of having host language 
proficient children from the three negative effects mentioned earlier.

Efficiency also differs between immigrants since some individuals find it easier to learn a language than others. This may be an important factor in destination language acquisition. An immigrant that arrived older age is expected to show a weaker foreign language acquisition since younger individuals seem to have a greater capacity to learn languages for biological reasons (Service, 1993). There seems to be a critical age threshold beyond which an immigrant's learning of a foreign language may become considerably more difficult. Cognitive scientists refer to this as the critical period hypothesis according to which there is a critical age range in which individuals learn languages more easily and after which language acquisition is more difficult. Behavioral evidence has been supportive of this hypothesis: late learners tend to attain a lower level of language proficiency. While there is no general consensus on the critical period age, most studies find supportive evidence of the critical period hypothesis, with the range between 5 and 15 (Chiswick \& Miller, 2008a). Moreover, educational attainment is expected to have a positive impact on foreign language acquisition. More educated individuals may have a greater learning ability (innate or acquired in school) or other unobserved variables (motivation) that enhance both educational attainment and language skill acquisition. Additionally, an individual's mother tongue and its distance to the destination language (Spanish) will also affect foreign language acquisition. The linguistic distance between other Romance languages including French, Romanian, Portuguese, Italian and Spanish is considerably smaller that between nonRomance languages and Spanish. According to Ethnologue: Languages of the World (2009), Spanish shares $89 \%$ of lexical similarity with Portuguese, $82 \%$ with Italian, 75\% with French and 71\% with Romanian. The shorter the linguistic distance between 
the mother tongue and the destination language, the greater the efficiency learning a destination language. Chiswick and Miller (1998, 2005) develop a quantitative measure of the distance between English and a set of other languages. In particular, they create an index for English, based on the ability of Americans to learn a variety of foreign languages in a given period of time. More recently, Isophording and Otten (2013) have used the Levenshtein distance to analyze the effect of linguistic distance on the acquisition of host language proficiency in the US, Germany and Spain. Both studies show that linguistic distance has a negative impact on immigrant's language proficiency. Linguistic distance may actually be related to the self-selection of immigrants. An example is the large amount of Romanians moving to Spain in the period 2001-2009. Romanians have become the largest immigrant group in Spain. Romanian is a Romance language and its proximity to Spanish makes language acquisition easier for Romanian immigrants. Interestingly Chiswick, Benstock and Repetto (2001) separate country of origin effects from language of origin effects in the acquisition of Hebrew language skills in Israel. Their results show that immigrants from most language origins are less proficient in Hebrew than those from Arabic-speaking countries. Arabic is the closest language to Hebrew, which is consistent with its Semitic origin. Interestingly, English speakers are the least proficient in speaking, reading and writing Hebrew as they make slower progress than others towards Hebrew language acquisition. These findings point to the existence of linguistic distance effects in destination language acquisition. The disadvantage for English speakers may derive from the fact that English is an international language and therefore reduces the incentive for immigrants to learn Hebrew. Their analysis shows the importance of both country of origin and linguistic distance in foreign language learning. Last but not least 
multilingual individuals are better prepared to learn additional foreign languages since they have developed more sophisticated learning methods, have a wider array of communicative strategies and possess stronger metalinguistic and cultural awareness. To our knowledge, the inclusion of the number of foreign languages spoken by immigrants as a determinant of host language acquisition has not been used in previous research.

The third set of factors includes economic incentives. The longer the expected period of residency in the destination country, the stronger the incentive for immigrants to acquire host language skills will be. Dustmann (1999) uses data from the German SocioEconomic Panel to analyze whether temporary immigrants' acquisition of language skills is sensitive to their intended duration of residence in the host country. His results show clearly that those who intend to remain permanently have a higher chance of being proficient in the host language. We include a variable on whether the immigrant is planning to return to his home country in the next 5 years. Language fluency is thus negatively affected by the migrant's propensity to return. This suggests that immigrants who plan to remain a longer period of time in the host country have a stronger incentive to invest in human capital.

Finally, additional differences amongst immigrants may be captured by a variable that shows their region of origin. These differences may include the quality and transferability of education, work experience received in their home country or the economic and political environment at the time of migration. 


\section{Data and definition of variables}

The data is taken from the Spanish National Immigrant Survey (Encuesta Nacional de Inmigrantes), a large-scale immigration survey carried out by the Spanish National Statistics Institute. The data collection was conducted between November 2006 and February 2007 and was based on the Municipal Census (Padrón Municipal). The original survey sample comprises approximately 15,500 individuals. The NIS provides detailed information on the socio-demographic characteristics of immigrants and their residential and work experience at home and in Spain. Immigrants are defined as any individual born abroad (regardless of their nationality) who at the time of being interviewed had reached at least 16 years of age and had resided in Spain for at least a year or longer or had the intention to remain in the country for at least a year ${ }^{1}$.

The estimating sample consists of immigrant men and women originally from nonSpanish speaking countries that are between 18 and 65 years old. A separate analysis is carried out for men and women due to potential gender differences derived from exposure and economic incentives. Because men are more likely to participate in the labor market than women, they have more incentives to learn the language, and, as they are employed, are also more strongly exposed to the destination language (Epenshade and $\mathrm{Fu}, 1997)$. However, gender differences may vary across immigrant groups. We will note the cases in which the direction or the strength of the estimated coefficients varies significantly between men and women. Dropping observations, including item non-response, leaves us with a final sample of 3,451 men and 3,085 women.

\footnotetext{
${ }^{1}$ Target population of the NIS.
} 
Fortunately, the Spanish National Immigrant Survey used for this article includes questions on the number and types of foreign languages spoken by immigrants in Spain. This allows us to include the number of foreign languages spoken as a unique and distinct variable to analyze the acquisition of Spanish language proficiency amongst immigrants in Spain. To our knowledge, this variable has never been taken into consideration in previous studies that analyze the acquisition of host language knowledge.

\subsection{Spanish proficiency}

The Spanish proficiency question on the NIS is:

- Thinking of what you need for communicating at work, at the bank, with the public authorities/administration. How well do you speak Spanish?

Answers range from 1 ('very well') to 4 ('need to improve'). These responses were used to define $S P$, a dummy variable that takes value one if the immigrant speaks Spanish adequately (1-very well, well), zero otherwise ${ }^{2}$.

The use of subjective evaluations is standard in the field, partly due to the high costs of test-based assessments of language ability. Admittedly respondents may have different perceptions under identical circumstances of how well they speak a foreign language. This notwithstanding, subjective questions are typically found to be highly correlated

\footnotetext{
2 The standard procedure in the literature is to establish one category for very well and well and another one for the rest (Dustmann 1997, Chiswick, Lee and Miller 2005, Isophording and Otten 2013. A dichotomous dependent variable reduces the probability of misclassification and, therefore, the extent of bias (Dustmann and van Soest, 2001). Results under the alternative classification 1 against 2-4 are available upon request.
} 
with scores from tests designed to accurately measure language skills as well as functional measures of language skills’ (Bleakley \& Chin, 2010).

Table 1 shows frequencies and percentages by language proficiency level for men and women. Nearly $73 \%$ of the total sample reports being proficient in Spanish, whereas the remaining $17 \%$ has more limited host language fluency. There are minor disparities between the two sub-samples. Interestingly women are slightly more proficient than men, with $40.93 \%$ of women speaking Spanish very well while just $38.84 \%$ of men show strong language ability.

Respondents in the NIS are also asked to self-assess (yes/no) whether they possess a satisfactory skill level in different areas, including comprehension, speaking, reading and writing ${ }^{3}$. In order to minimize concerns about the over-reporting of language ability, some studies define language proficiency as the self-reported ability to read and write (Casale \& Posel, 2011) or the ability to speak and write (Di Paolo, 2011). Moreover, the available evidence suggests that different areas of knowledge may have. In spite of the potential interest, the present paper does not attempt to differentiate between different types of skills. The main reason is a practical one: the information included in the NIS on comprehension, speaking, reading and writing is provided on a yes/no basis, and as many as $99.8 \%$ (comprehension), 100\% (speaking), $92.0 \%$ (reading) and $84.8 \%$ (writing) of the sample answer 'yes' to the corresponding question.

\footnotetext{
3 The precise wording of the question is: "Besides_____mother tongue), what other languages do you know? Tell me up to a maximum of six languages, in the event that you know more". Then, the following sequence is repeated 6 times: Language Comprehension? 1. Yes. 2. No; can you speak this language? 1. Yes. 2. No; can you read in this language? 1. Yes. 2. No; can you write in this language? 1. Yes. 2. No. Immigrants whose mother tongue is Spanish are not required to provide such information, the underlying assumption being that they are fully proficient in the four areas.
} 
These figures are higher than the $72.9 \%$ of proficient immigrants that emerge from the central question used in the paper. Therefore, relying on these indicators provides a far less stringent criterion for language proficiency.

\section{Estimation strategy}

The language proficiency equation is estimated by means of a probit model. Reported language proficiency, SP, is assumed to be a function of a latent variable SP* that is not measured, is continuous, has a threshold point that determine the observed value of SP, and is a function of observable characteristics

$$
S P_{i}^{*}=X_{i} \alpha+E_{i} \beta+F_{i} \gamma+I_{i} \delta+\varepsilon_{i}
$$

$$
\begin{aligned}
& S P=1 \text { if } S P^{*}>0 \\
& S P=0 \text { if } S P^{*} \leq 0
\end{aligned}
$$

$\mathrm{X}$ contains a vector of ones and dummy variables capturing the geographical area of origin (Eastern Europe, Western Europe, the Maghreb -Northern Africa, Sub-Saharan Africa, LatinAmerica and the USA/Canada/Australia) and, therefore, cultural and educational regional differences. Vectors $E, F$ and $I$ include the exposure, efficiency, and economic incentives variables, respectively. Specifically, E includes years since migration and its square, marital status (married or not), children at home (yes/no) and whether the children are proficient in Spanish (proficient/non-proficient). $F$ includes age at arrival, years of schooling, Romance mother language (yes/no), number of foreign languages spoken by the immigrant and whether 
she lives in one of Spain's bilingual region. Finally, I captures whether the immigrant is planning to return to his home country in the next 5 years.

Following the prevailing results obtained in the literature, we expect immigrants that arrived at an older age to be less fluent in Spanish. The length of their period of residence in Spain should also be positively associated but at a decreasing rate and the immigrant's level of educational attainment should be positively correlated with his Spanish speaking fluency. The number of children may affect the parents' host language skills differently depending on their gender, but the child's Spanish language proficiency is definitely expected to have a positive impact for both genders. Romance mother language background is positively related to linguistic distance and is therefore expected to have a positive impact on Spanish language acquisition and the number of additional foreign languages spoken by the individual are expected to have a positive effect on destination language learning. Finally, planning to stay in Spain more permanently is predicted to have a positive impact.

Summary statistics by gender are provided in Table 2. The fraction of language proficient immigrants is strikingly similar between men-72.93\% and women- $72.95 \%$. Immigrant men are slightly older-38.5 years than women-37.4 and arrived in Spain at older age-26.7 years than women-27.3. As a result, immigrant men have resided in Spain for roughly 1.6 years longer than women. This probably reflects the fact that the male immigrant moves initially in order to find a job and adequate housing, and his female partner and children arrive later when the family is more certain to settle for a longer period in the destination country. Furthermore females are more educated educational than men and are more prevalent among Romance language speakers. This 
is mainly due to that fact that Romanian immigration is predominantly female (56\%). The number of foreign languages spoken hardly varies between genders. A larger fraction of male immigrants are married and women are slightly more likely to live with their children. Regarding region of origin male immigrants are mainly from Western Europe (29\%), Northern Africa (28\%) and Eastern Europe (26\%) while female immigrants are predominantly from Eastern (38\%) and Western Europe (31\%).

\section{Results}

Our first specification includes independent variables capturing the effect of age at migration, years since migration (and its square), educational attainment, whether the immigrant is married, has children and if their children are proficient in Spanish, if they live in a Spanish bilingual region and if they plan to stay in Spain more permanently. In the second specification we add the two language variables. One for the number of foreign languages that the immigrant speaks and another variable capturing whether the migrant's mother language descends from Latin.

Estimations are performed separately for men and women. Table 3 reports the coefficients, their standard errors and the marginal effects at the mean of the covariates for men and Table 4 shows the corresponding results for women. We discuss the results for the second specification considering that it includes the relevant language variables that are preeminent for our research. The results confirm a strong and statistically significant positive effect of speaking an additional foreign language on the probability of reporting good or very good Spanish language proficiency for men and women. The coefficients are strikingly similar for men and women, for every additional foreign 
language spoken the probability of being proficient in Spanish increases by $6.2 \%$, for men and $6 \%$ for women which is equivalent to the impact three years of educational attainment for women and seven years of education for men. Interestingly, adjusting for the number of foreign languages spoken reduces the impact of education on Spanish language proficiency. These results appear to show that the coefficients for education obtained in previous studies may overestimate the impact of educational attainment on host language learning. Furthermore, Romance mother language influence further increases the probability of reporting higher Spanish language ability by 16 percentage points for men and 10 percentage points for women.

As expected, education is positively associated with host language learning at around $1 \%$ per additional year of education for men and $2 \%$ for women, which is substantially lower than the returns obtained for Spain and other countries (Isophording, 2012, Chiswick and Miller 2008b) considering that the considerably positive impact of multiple foreign language knowledge on host language learning has not been taken into account in other studies. This shows that the effect of formal education may have been overstated in previous research. Moreover, the immigrant children's host language proficiency has not been considered in other studies. More educated individuals are more likely to speak several foreign languages and their children may be more inclined to learn the host language more rapidly and act as teachers for their parents.

The rest of the coefficients show similar results than those revealed by other studies and are in line with theoretical hypothesis. Age at migration is negatively associated with host language acquisition at $0.6 \%$ for men and $0.3 \%$ for women per year. Moreover, an extra year of residence in Spain increases the probability of being proficient by $2.7 \%$ for 
men and $1.8 \%$ for women at a decreasing rate as shown in previous studies. That is, migrating at an older age penalizes men more than women, but for every additional year in the destination country, men acquire language skills at a stronger pace. Planning to stay in Spain for the next five years is positively associated with destination language acquisition as expected, due to the fact that the longer the immigrant is planning to remain in the destination country, the stronger the incentives to invest in host language acquisition given that the return will be seized over a longer period of time.

The impact of immigrant children on their parent's destination language proficiency deserves a separate and more extensive comment. The National Immigrant Survey allows us to adjust for whether the immigrant has children and more importantly if their child speaks Spanish well. Research carried out previously does not allow for this partition and is therefore not able to insulate the positive effect of learning Spanish from their children from the several negative effects derived from speaking the home language in the household and having children act as translators. As expected, the results show that having a child that speaks Spanish well or very well is strongly associated with their parent's host language skills. The impact is roughly equivalent to speaking an additional foreign language both for men and for women. Moreover when the positive impact of having a child that acts as a destination language teacher has been taken into account, it is possible to isolate negative effects of having children that serve as translators and parents who seek to transmit the culture of their home country to their children, limiting the chance to develop destination language skills amongst family members. The results strongly support the negative effect and interestingly show that it is considerably stronger for women since children may also affect their labor supply, reducing their chance and incentive to acquire host language skills. Being married is not 
statistically significant since the data does not allow us to distinguish whether their spouse is Spanish.

Lastly living in a Spanish bilingual region-Catalonia, Balearic Islands, Basque Country, Valencia and Galicia is positively associated to the probability of reporting good or very good Spanish language proficiency. Perhaps living in a multilingual region in Spain increases the immigrants' awareness and exposure to host languages or immigrants that move to these areas are more willing to accept and learn different languages.

\section{Conclusion}

This study is concerned with the determinants of Spanish language proficiency for immigrants in Spain. The results and patterns found for Spanish language acquisition are similar to those obtained in previous analyses for other major immigrant recipient countries like Germany, the United States, Canada, Australia and Israel. Considering that this is one of the few analyses carried out in a non-English speaking country and as English has become an international lingua franca, it is relevant to confirm whether similar patterns are found for a non-English speaking country.

Most importantly, our results provide new evidence that shows the usefulness of multiple language proficiency and how multilingualism contributes to the immigrant's acquisition of host language skills. Research in Spain (Sanz, 2000) and in other countries (Cenoz 2013) shows that being multilingual strengthens subsequent foreign language acquisition and the data from the NIS contains valuable information about the number of additional foreign languages spoken by immigrants in Spain. This allows us to introduce a unique explanatory variable to investigate Spanish language learning 
amongst immigrants in Spain. As expected, the results confirm a strong positive effect of speaking additional foreign languages on the probability of reporting good or very good Spanish language proficiency for immigrant in Spain. Furthermore, adjusting for number of foreign languages spoken reduces the impact of educational attainment on Spanish language proficiency, revealing that the effect of education on host language learning may have been overestimated in previous studies. Lastly, our paper shows the importance of isolating the effect of having children that speak the host language from the rest of the consequences of having children. Adjusting for the children's Spanish proficiency, descendants living in the household affect destination language learning negatively and the impact is stronger for women as expected.

Cultural, social and economic assimilation in the destination country are essential for keeping a cohesive and stable society, especially under the particular circumstances of massive newly arrived immigration and a long period of economic recession that has led to a $24 \%$ level of unemployment in Spain. From an analytical point of view the problem arises from the concept of assimilation and the difficulty of measuring it. Earnings, employment and language skills are easier to measure than culture, traditions and values. We analyze the determinants of Spanish language proficiency since destination language acquisition contributes to cultural and social assimilation.

Our results are important to enable policy makers to devise strategies and immigration policies that promote and guarantee economic and social stability. The analysis shows that immigrants that are better educated, speak multiple foreign languages, have children that speak the host language and plan to stay in Spain for a longer period of time, show stronger Spanish language ability. As a consequence, it would be advisable 
to set up extensive introductory programs for immigrants that should partly consist of Spanish language instruction, and classes should be organized by education level and familiarity of foreign languages by participants to ensure adequate learning. There is a need for professional development in teaching Spanish as a second language.

A common policy priority in OECD countries is labour market integration and the strengthening of educational aspects, including language training (OECD, 2012). In line with this view, the Spanish Strategic Plan for Citizenship and Integration acknowledged the fact that immigration poses specific challenges that must be tackled, such as "the promotion of improvements in immigrants' knowledge of the official languages and social norms in Spain, prerequisites for a cohesive society and for the social integration of immigrants” (Ministry of Labour and Social Affairs, 2007). This paper sheds further light on this issue by identifying and assessing the key players in the destination language learning process. In doing so, the analysis takes a step towards the diagnosis of the main benefits that immigrants from different socio-economic and educational backgrounds may obtain from language training programmes.

This research has also important implications for understanding and predicting Spanish language experiences for immigrants from various geographical areas. The results show that Asian immigrants and male immigrants from Northern Africa seem to be at language disadvantage and may require more intensive Spanish training programs at arrival. Finally, policies that favor permanent migration over temporary migration would also allow for a more rapid better social and economic integration. It may provide immigrants with a longer time horizon to capture the return from their investment in host language skills. 


\section{References}

Adsera, A. and Chiswick, B. (2007). 'Are there gender and country of origin differences in immigrant labor market outcomes across European destinations?, Journal of Population Economics, 20(3), pp.495-526.

Amuedo-Dorantes, C. and de la Rica, S. (2007). 'Labor market assimilation of recent immigrants in Spain’, British Journal of Industrial Relations, 45(2), pp. 257-284.

Beenstock, M., Chiswick, B.R., and Paltiel, A., (2010). 'Testing the Immigrant Assimilation Hypothesis with Longitudinal Data', Review of Economics of the Household, 8(1), pp. 7-27.

Beiser, M., and Hou, F. (2006), 'Learning the language of a new country: a ten-year study of English acquisition by South-East Asian refuges in Canada', International Migration, 44 (1), pp. 135-165

Berman, E., Lang K., and Siniver E. (2003) 'Language-skill complementarity: returns to immigrant language acquisition’, Labour Economics, 10(3),pp.265-290.

Bialystock, E. (1988) 'Levels of bilingualism and levels of linguistic awareness', Developmental Psychology, 24(4), pp.560-567

Blázquez, M. and S. Rendón (2012), 'Over-education in multilingual economies: Evidence from Catalonia', forthcoming on International Migration, 50 (1)

Bleakley, H., and Chin, A. (2010). 'Age at Arrival, English Proficiency, and Social Assimilation among US Immigrants', American Economic Journal: Applied Economics, American Economic Association, 2(1), pp. 165-92.

Budría, S. and Swedberg, P. (2014). 'The impact of language proficiency on immigrants' earnings in Spain', forthcoming on Revista de Economía Aplicada 
Carliner, G. (1981). 'Wage differences by language group and the market for language skills in Canada', The Journal of Human Resources, 16(3), pp. 384-399.

Casale, D. and Posel, D. (2011). 'English language proficiency and earnings in a developing country: the case of South Africa', Journal of Socio-Economics, 40, pp. 385-393.

Cenoz, J. (2013). 'The influence of bilingualism on third language acquisition: focus on multilingualism', Language Teaching, 46(1), pp. 71-86.

Chiswick, B. (1991). 'Speaking, Reading, and Earnings among Low-Skilled Immigrants'. Journal of Labor Economics, 9(2), pp.149-170

Chiswick, B. (1998). 'Hebrew language usage: Determinants and effects on earnings among immigrants in Israel', Journal of Population Economics, 11, pp. 253-271.

Chiswick, B. and Miller, P. (1995). 'The Endogeneity between language and earnings: international analyses', Journal of Labor Economics, 13(2), pp. 246-288.

Chiswick, B. and Miller, P. (1994). 'Language Choice Among Immigrants in a Multi-Lingual Destination'. Journal of Population Economics, 7(2), pp. 119-131

Chiswick, B. and Miller, P. (1998). 'Language skill definition: a study of legalized aliens'. International Migration Review, 32(4), pp. 877-900

Chiswick, B. and Miller, P. (1999a). 'Language skills and earnings among legalized aliens'. Journal of Population Economics, 12, pp. 63-89.

Chiswick, B. and Miller, P. (2001). 'A model of destination-language acquisition: application to male immigrants in Canada'. Demography, 38, 3, pp.391-409.

Chiswick, B. and Repetto, G. (2001). 'Immigrants Adjustment in Israel: The Determinants of Literacy and Fluency in Hebrew and the Effects on Earnings' International Migration: Trends, Policy and Economic Impact, New York: Routledge, 2001, pp. 204-228. 
Chiswick, B., Beenstock, M., and Repetto, G. (2001). 'The Effect of Linguistic and Country of origin on Immigrant Language Skills: Application to Israel', International Migration, 39(3), pp.33-60.

Chiswick, B. and Miller, P. (2005). 'Linguistic Distance: a Quantitative Measure of the Distance between English and other Languages', Journal of Multilingual and Multicultural Development, 26, pp. 1-11

Chiswick, B., Lee, Y.L. and Miller, P. (2004). 'Immigrants' language skills: the Australian experience in a longitudinal survey’, International Migration Review, 38 (2), pp. 611-654

Chiswick, B., Lee, Y.L. and Miller, P. (2005).'Family Matters: The role of the family in Immigrants' destination language acquisition', Journal of Population Economics, 18 (4), pp. $631-647$

Chiswick, B., Lee, Y.L. and Miller, P. (2005). 'Parents and Children Talk: English Language Proficiency within Immigrant Families' Review of Economics of the Household, 3, pp.243268.

Chiswick B. and Miller, P. (2008a). 'A test for critical period hypothesis for language learning'. Journal of Multilingual and Multicultural Development, 29(1), pp. 16-29.

Chiswick, B. and Miller, P. (2008b). 'Modeling Immigrants' language skills'. Research in Labor Economics, 27, pp. 75-128.

Chiswick, B. and Miller, P. (2010). 'Occupational language requirements and the value of English in the US labor market', Journal of Population Economics, 23, pp. 353-372.

Dustmann, C. (1994). 'Speaking fluency, writing fluency, and earnings among migrants', Journal of Population Economics, 7(2), pp. 133-156.

Dustmann, C. (1997). 'The Effects of Education, Parental Background and Ethnic Concentration on Language' The Quarterly Review of Economics and Finance, 37, pp.245262. 
Dustmann, C. (1999). 'Temporary Migration, Human Capital, and Language Fluency of Migrants' Scandinavian Journal of Economics, 101, pp.297-314.

Dustmann, C, and van Soest, A. (2001). 'Language fluency and earnings: estimation with misclassified language indicators', The Review of Economics and Statistics, 83(4), pp. 663674.

Dustmann, C, and van Soest, A. (2001). 'Language and the earnings of immigrants', Industrial and Labor Relations Review, 55(3), 473-492.

Dustmann, C. and Fabbri, F. (2003). 'Language proficiency and labor market performance of immigrants in the UK', The Economic Journal, 113, pp. 695-717.

Epenshade, T., and Fu, H. (1997). 'An Analysis of English Language Proficiency among U.S. Immigrants'. American Sociological Review, 62, 2, pp. 288-305

European Commission (2009). 'Study on the contribution of multilingualism to creativity: Final report’. Brussels: European Commission

European Comission (2012). 'Europeans and their languages', Eurobarometer Special Survey No.386. Available at: http://ec.europa.eu/public_opinion/archives/ebs/ebs_386_en.pdf

Fernández, C. and Ortega, C. (2008). 'Labor market assimilation of immigrants in Spain: employment at the expense of bad job-matches?', Spanish Economic Review, 10, pp. 83-107

Friedberg, R. (2000). 'You can't take it with you? Immigrant assimilation and the portability of human capital', Journal of Labor Economics, 18(2), pp. 221-251.

Goza F., and Kayamura, S. (2013). 'English acquisition and Japanese language maintenance among Japanese-American youth’, International Migration, 51 (5), pp. 149-171

Grenier, G. (1984). 'The Effects of language characteristics on the wages of HispanicAmerican males', The Journal of Human Resources, 19, pp. 33-52. 
Hayfron, J. (2001). 'Language training, language proficiency and earnings of immigrants in Norway', Applied Economics, 33, pp. 1971-1979.

Hu, W-Y. (2000). 'Immigrant earnings assimilation: estimates from longitudinal data. American Economic Review, Papers and Proc. 90 (May): 368-372.

Instituto Nacional de Estadística (2014). 'Estadística de Migraciones 2013’, INE. Available at: http://www.ine.es/jaxi/menu.do?type=pcaxis\&path=\%2Ft20\%2Fp277\&file=inebase\&L=0

Isophording, I. E. and Otten, S. (2013). ' The Cost of Babylon-Linguistic Distance in Applied Economics', Review of International Economics, 21(2), pp. 354-369.

Kulkarni, V.S., and Hu X. (2014). 'English language proficiency among the foreign born in the United States, 1980-2007: Duration, age and cohort effect', forthcoming on International Migration Review

Lacuesta, A., Izquierdo, M., and Vegas, R. (2009). 'Assimilation of immigrants in Spain: A longitudinal analysis', Labour Economics, 6(6), pp. 669-678.

Lewis, M.P. (ed.), (2009). Ethnologue: Languages of the World, Sixteenth edition. Dallas, Texas: SIL International.

Lubotsky, D., (2007). 'Chutes or Ladders: A Longitudinal Analysis of Immigrant Earnings', Journal of Political Economy, 115(5), pp.820-867.

Lui, H.K. (2007). 'The returns to language ability in Hong Kong: before and after the handover’, Applied Economic Letters, 14(2), pp. 121-125.

Marian, V. and Shook, A. (2012). 'The cognitive benefits of being bilingual', Cerebrum, 12.

Medvedeva M. (2012). 'Negotiating languages in immigrant families’, International Migration Review, 46 (2), pp. 517-545

McManus, W., Gould, W. and Welch, F. (1983). 'Earnings of Hispanic men: the role of English language proficiency’, Journal of Labor Economics, 1(2), pp.101-130. 
Ministry of Labour and Social Affairs (Ministerio de Trabajo y Asuntos Sociales) (2007).

'Strategic plan for citizenship and integration’, Subdirección General de Información Administración y Publicaciones. Available at:

http://extranjeros.empleo.gob.es/es/IntegracionRetorno/Plan_estrategico/pdf/PECIingles.pdf

OECD (2012). 'Migration policy developments’ International Migration Outlook 2012, OECD Publishing. Available at: http://dx.doi.org/10.1787/migr outlook-2012-6-en

OECD (2013). 'Migration policy developments', International Migration Outlook 2013, OECD Publishing. Available at: http://www.oecd.org/els/mig/imo2013.htm

Raijman, R. (2013). 'Linguistic Assimilation of First-Generation Jewish South-African Immigrants in Israel', Journal of International Migration and Integration, 14, pp. 615-636.

Rebhun, U. (2014). 'English-language proficiency among Israeli Jews and Palestinian Arabs in the United States, 1980-2000', forthcoming on International Migration Review,

Rivera-Batiz, F. (1992). 'English proficiency and the earnings of young immigrants in the U.S. Labor Markets', Review of Policy Research, 11(2), pp. 165-175.

Sanz, C. (2000). "Bilingual education enhances third language acquisition: Evidence from Catalonia.” Applied Psycholinguistics (Psychological Studies of Language Processes) 21, pp. 23-44.

Service, E. (1993). 'Differences between Young and Older Adults in Learning a Foreign Vocabulary' Journal of Memory and Language, 32, pp.608-623

Simón, H., Sanromá, E. and Ramos, R. (2008). 'Labour segregation and immigrant and nativeborn wage distributions in Spain: an analysis using matched employer-employee data', Spanish Economic Review, 10(2), pp.135-168.

Shields, M. and Price, S. (2002). 'The English language fluency and occupational success of ethnic minority immigrant men in English metropolitan areas' Journal of Population Economics, 15, pp.137-160 
Tainer, E. (1988). 'English Language Proficiency and the Determinants of Earnings among Foreign-Born Men’ The Journal of Human Resources, 23(1), pp.108-122.

Thomas, K. (2010). 'Household context, generational status and English proficiency among the children of African immigrants in the U.S.', International Migration Review, 44 (1), 142172.

van Tubergen, F. and and Kalmijn M. (2009). 'A dynamic approach to the determinants of immigrants language proficiency: the United States, 1980-2000'International Migration Review, 43(3), pp. 
Tables

Table 1: Summary statistics by gender

\begin{tabular}{|c|c|c|c|}
\hline & & Men & Women \\
\hline Share & & 0.528 & 0.472 \\
\hline Proficienct in Spanish & $\boldsymbol{r}$ & $\begin{array}{c}0.729 \\
(0.444)\end{array}$ & $\begin{array}{r}0.729 \\
(0.444)\end{array}$ \\
\hline Age & $\boldsymbol{F}$ & $\begin{array}{l}38.504 \\
(10.736)\end{array}$ & $\begin{array}{l}37.423 \\
(11.570)\end{array}$ \\
\hline Age at arrival & $\boldsymbol{r}$ & $\begin{array}{l}26.73 \\
(9.604)^{\circ}\end{array}$ & $\begin{array}{l}27.336 \\
(10.854)\end{array}$ \\
\hline Years since migation & . & $\begin{array}{c}11.774^{\gamma} \\
(12.112)^{\gamma}\end{array}$ & $\begin{array}{l}10.087 \\
(12.564)\end{array}$ \\
\hline Educational attainment & $\boldsymbol{r}$ & $\begin{array}{l}9.532 \\
(4.795)^{\circ}\end{array}$ & $\begin{array}{r}10.221 \\
(4.396)\end{array}$ \\
\hline With children & $\boldsymbol{F}$ & $\begin{array}{c}0.626 \\
(0.483)\end{array}$ & $\begin{array}{r}0.648 \\
(0.477)\end{array}$ \\
\hline Child speaks Spanish & $\boldsymbol{F}$ & $\begin{array}{c}0.324 \\
(0.468)\end{array}$ & $\begin{array}{l}0.372 \\
(.483)\end{array}$ \\
\hline Married & $\boldsymbol{r}$ & $\begin{array}{c}0.624 \\
(0.484)\end{array}$ & $\begin{array}{r}0.541 \\
(0.498)\end{array}$ \\
\hline Romance mother language & $\boldsymbol{F}$ & $\begin{array}{c}0.399 \\
(0.489)\end{array}$ & $\begin{array}{r}0.443 \\
(0.496)\end{array}$ \\
\hline Number of foreign languages & $\boldsymbol{r}$ & $\begin{array}{l}2.046^{\circ} \\
(1.089)^{\circ}\end{array}$ & $\begin{array}{r}1.998 \\
(1.053)\end{array}$ \\
\hline Bilingual region in Spain & $r$ & $\begin{array}{r}.376^{\circ} \\
(.484)^{\circ}\end{array}$ & $\begin{array}{r}.360 \\
(480)\end{array}$ \\
\hline Plans to stay in Spain & $\boldsymbol{r}$ & $\begin{array}{c}0.837 \\
(0.369)\end{array}$ & $\begin{array}{l}0.817 \\
(0.386)\end{array}$ \\
\hline
\end{tabular}

\section{Region of origin}

Northern Africa

\begin{tabular}{|c|c|c|}
\hline & $\begin{array}{c}0.283 \\
(0.450)\end{array}$ & $\begin{array}{r}0.167 \\
(0.373)\end{array}$ \\
\hline & $\begin{array}{c}0.065 \\
(0.248)\end{array}$ & $\begin{array}{r}0.029 \\
(0.168)\end{array}$ \\
\hline$r$ & $\begin{array}{c}0.259 \\
(0.438)\end{array}$ & $\begin{array}{r}0.378 \\
(0.485)\end{array}$ \\
\hline$F$ & $\begin{array}{c}0.288 \\
(0.453)\end{array}$ & $\begin{array}{r}0.306 \\
(0.461)\end{array}$ \\
\hline & $\begin{array}{c}0.042 \\
(0.201)\end{array}$ & $\begin{array}{r}0.075 \\
(\mathbf{0 . 2 6 4 )}\end{array}$ \\
\hline 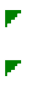 & $\begin{array}{c}0.009^{\top} \\
(.098)^{r}\end{array}$ & $\begin{array}{r}.010 \\
(.101)\end{array}$ \\
\hline & $\underset{(0.218)}{0.05}$ & $\begin{array}{r}0.031 \\
(0.175)\end{array}$ \\
\hline
\end{tabular}

Asia 
Table 2: Language Proficiency Males and Females

\begin{tabular}{lrrrr}
\hline & Men & \multicolumn{3}{c}{ Women } \\
\hline Share & 0.528 & \multicolumn{3}{c}{0.472} \\
& Frequency & Percentage & Frequency & Percentage \\
Very good & 1342 & 38.84 & 1265 & 40.93 \\
Good & 1178 & 34.1 & 990 & 32.03 \\
Total proficient & 2520 & 72.94 & 2255 & 72.96 \\
Sufficient & 484 & 14.01 & 422 & 13.65 \\
Needs to improve & 451 & 13.05 & 414 & 13.39 \\
Total non-proficient & 935 & 27.06 & 836 & 27.04
\end{tabular}

Table 3: Spanish immigrant language skills MEN

\begin{tabular}{|c|c|c|c|c|c|c|}
\hline & \multicolumn{3}{|c|}{ (i) MODEL A } & \multirow{2}{*}{$\frac{\text { (ii) }}{\text { Coeff. }}$} & \multicolumn{2}{|l|}{ IODEL B } \\
\hline & Coeff. & S.E & M.E. & & S.E. & M.E. \\
\hline Age at arrival & $-.025^{*} * * *$ & $(.003)$ & $-.007 * * *$ & $-.022 * * *$ & $(.003)$ & $-.006^{* * * *}$ \\
\hline Years since migration & $.085 * * *$ & $(.010)$ & $.025^{* * *}$ & $.095^{* * *}$ & $(.010)$ & $.027 * * *$ \\
\hline Years since migration square & $-.113 * * *$ & $(.028)$ & $-.033 * * *$ & $-.143 * * *$ & $(.028)$ & $-.041 * * *$ \\
\hline Educational attainment & $.052 * * *$ & $(.005)$ & $.015^{* * *}$ & $.038 * * *$ & $(.006)$ & $.010^{* * *}$ \\
\hline Children & $-.281 * * *$ & $(.069)$ & $-.080 * * *$ & $-.228 * * *$ & $(.070)$ & $-.064 * * *$ \\
\hline Child speaks Spanish & $.259 * * *$ & $(.068)$ & $.073^{* * *}$ & $.230 * * *$ & $(.069)$ & $.064 * * *$ \\
\hline Married & $-.119 *$ & $(.064)$ & $-.034 *$ & -.073 & $(.065)$ & -.020 \\
\hline Romance mother language & & & & $.586^{* * *}$ & $(.069)$ & $.160 * * *$ \\
\hline Number of foreign languages & & & & $.218^{* * *}$ & $(.029)$ & $.062 * * *$ \\
\hline Bilingual region & $.234 * * *$ & $(.053)$ & $.067 * * *$ & $.146^{* * * *}$ & $(.055)$ & $.041^{* * *}$ \\
\hline Plans to stay in Spain & $.164 * *$ & $(.065)$ & $.050^{* * *}$ & $.209^{* * *}$ & $(.066)$ & $.063^{* * *}$ \\
\hline \multicolumn{7}{|l|}{ Region of origin } \\
\hline Maghreb & $-.551 * * *$ & $(.083)$ & $-.175 * * *$ & $-.278 * * *$ & $(.093)$ & $-.083^{* * *}$ \\
\hline Sub-saharan Africa & $-.798 * * *$ & $(.110)$ & $-.284 * * *$ & $-.670 * * *$ & $(.116)$ & $-.231 * * *$ \\
\hline Eastern Europe & $-.363 * * *$ & $(.079)$ & $-.113 * * *$ & $-.341 * * *$ & $(.081)$ & $-.104 * * *$ \\
\hline Latin-America & .076 & (.149) & .021 & .006 & $(.153)$ & .001 \\
\hline Asia & $-.653 * * *$ & $(.122)$ & $-.228 * * *$ & $-.349 * * *$ & $(.128)$ & $-.112 * * *$ \\
\hline USA, Canada \& Australia & .433 & $(.403)$ & .105 & $.793 * *$ & $(.391)$ & $.156^{* *}$ \\
\hline Pseudo-R ${ }^{2}$ & .172 & & & .201 & & \\
\hline Number of observations & 3,451 & & & 3,451 & & \\
\hline
\end{tabular}


Table 4: Spanish immigrant language skills WOMEN

\begin{tabular}{|c|c|c|c|c|c|c|}
\hline & \multicolumn{3}{|c|}{ (i) MODEL A } & \multirow{2}{*}{$\begin{array}{c}\text { (ii) } \\
\text { Coeff. }\end{array}$} & \multicolumn{2}{|c|}{ MODEL B } \\
\hline & Coeff. & S.E. & M.E. & & S.E & M.E \\
\hline Age at arrival & $-.015 * * *$ & $(.002)$ & $-0.04 * * *$ & $-.011 * * *$ & $(.002)$ & $-.003 * * *$ \\
\hline Years since migration & $.057 * * *$ & $(.009)$ & $.017 * * *$ & $.061 * * *$ & $(.009)$ & $.018 * * *$ \\
\hline Years since migration square & $-.059 * * *$ & $(.020)$ & $-.018 * * *$ & $-.066^{* * *}$ & $(.020)$ & $-.020 * * *$ \\
\hline Educational attainment & $.079 * * *$ & $(.006)$ & $.024 * * *$ & $.066^{* * * *}$ & $(.007)$ & $.020^{* * *}$ \\
\hline Children & $-.369 * * *$ & $(.068)$ & $-.108 * * *$ & $-.365^{* * * *}$ & $(.068)$ & $-.106^{* * *}$ \\
\hline Child speaks Spanish & $.240 * * *$ & $(.067)$ & $.072 * * *$ & $.260^{* * *}$ & $(.066)$ & $.077 * * *$ \\
\hline Married & .017 & $(.057)$ & .005 & .019 & $(.057)$ & .005 \\
\hline Romance mother language & & & & $.327 * * *$ & $(.065)$ & .097 *** \\
\hline Number of for eign languages & & & & $.198 * * *$ & $(.031)$ & $.060^{* * *}$ \\
\hline Bilingual region & $.183^{* * *} *$ & $(.056)$ & $.055^{* * *}$ & $.129 * *$ & $(.058)$ & $.038 * *$ \\
\hline Plans to stay in Spain & $.243^{* * *} *$ & $(.065)$ & $.078 * * *$ & $.269 * * *$ & $(.066)$ & $.086^{* * *}$ \\
\hline \multicolumn{7}{|l|}{ Region of origin } \\
\hline Maghreb & $-.217 * *$ & $(.089)$ & $-.070 * *$ & -.080 & $(.097)$ & -.024 \\
\hline Sub-saharan Africa & -.102 & $(.158)$ & -.032 & .002 & $(.163)$ & .000 \\
\hline Eastern Europe & .060 & $(.076)$ & .018 & .063 & $(.077)$ & .019 \\
\hline Latin-America & .063 & $(.111)$ & .019 & .048 & $(.114)$ & .014 \\
\hline Asia & $-.481 * * *$ & (.149) & $-.168 * * *$ & $-.307 * *$ & $(.154)$ & $-.102 *$ \\
\hline USA, Canada \& Australia & -.020 & $(.318)$ & -.006 & .160 & $(.319)$ & .045 \\
\hline $\mathrm{R}^{2}$ & .134 & & & .150 & & \\
\hline No. of observations & 3,085 & & & 3085 & & \\
\hline
\end{tabular}

